\title{
Penerapan Metode Tandur dan Melempar “Bola Salju” (T\&BS) Untuk Meningkatkan Hasil Belajar Pada Siswa SDN 8 Jenggik
}

Oleh:

Suhaili Munahar

\begin{abstract}
Abstrak: Penelitian ini bertujuan untuk meningkatkan hasil belajar siswa SDN 8 Jenggik melalui penerapan metode T \& BS. Berdasarkan hasil observasi dan wawancara dengan Guru kelas terdapat beberapa masalah pada waktu pembelajaran yaitu rendahnya hasil belajar siswa, rendahnya perhatian siswa terhadap proses pembelajaran. Untuk mengatasi permasalahan yang ada guru hendaknya memperbaiki sistem pembelajaran salah satu caranya dengan menerapkan metode Tandur dan melempar "Bola Salju" (T\&BS). Subjek penelitian ini adalah siswa kelas IV SDN 8 Jenggikyang berjumlah 24 orang. berdasarkan hasil observasi untuk aktivitas siswa pada siklus I diperoleh skor 44 dengan katagori aktif, sedangkan siklus II memperoleh skor 48 dengan katagori sangat aktif. Dan untuk pengelolaan pembelajaran pada siklus I yaitu 13 dengan katagori baik, sedangkan pada siklus II yaitu 17 dengan katagori baik sekali. Untuk nilai rata-rata siswa yaitu pada siklus I 73,19 menjadi 77,09 pada siklus II. Sehingga mengalami kenaikan 4 digit sedangkan ketuntasan belajar klasikal berdasarkan KKM yang ditetapkan yaitu $\geq 70$. Pada siklus I 68,18\% dan pada siklus II menjadi 82,60\% yang mengalami kenaikan 14 digit.
\end{abstract}

Kata kunci : Pembelajaran Tandur dan melempar "Bola Salju" (T\&BS), Hasil Belajar

Abstract: This study aims to improve student learning outcomes SDN 8 Jenggik through the application of methods of $T \& B$ BS. Based on observations and interviews with teachers of grades there are some problems at the time of learning as the low student learning, lack of attention to students' learning process. To overcome the existing problems teachers should improve the system of learning one way to apply the method Tandur and throws a "Snowball" (T \& BS). The subjects were students of class IV SDN 8 Jenggikyang totaling 24 people. based on the observation of the activity of students in the first cycle obtained a score of 44 in the category of active, while the second cycle obtain a score of 48 in the category are very active. And for learning management in the first cycle at 13 with good category, while in the second cycle which was 17 in the category very well. For the average value in the first cycle of students is 73.19 to 77.09 in the 
second cycle. So the 4-digit increases while the completeness of classical study by KKM set is $>70$. In the first cycle of $68.18 \%$ and the second cycle be $82.60 \%$ which increased 14 digits.

Keyword: Learning Tandur and throws a "Snowball" (T \& BS), Learning Outcomes

\section{PENDAHULUAN}

Menurut Kurikulum Berbasis Kompetensi yang disempurnakan dalam Kurikulum Tingkat Satuan Pendidikan bahwa setiap individu mempunyai potensi yang harus dikembangkan, maka proses pembelajaran yang cocok adalah yang menggali potensi anak untuk selalu kreatif dan berkembang.

Namun kenyataan dilapangan belum menunjukkan ke arah pembelajaran yang bermakna. Para pendidik masih menggunakan suatu pendekatan yang berpusat pada guru tanpa melibatkan siswa untuk ikut aktif dalam proses pembelajaran dan kegiatan belajar mengajar menjadi monoton, karena siswa pada umumnya hanya sebagai penerima informasi yang diberikan guru dalam proses pembelajaran berlangsung. Dengan demikian guru dituntut untuk memilih metode yang tepat, sehingga akan menciptakan pembelajaran yang aktif, kreatif, efektif, dan menyenangkan yang sesuai dengan kurikulum tingkat satuan pendidikan (KTSP).

“Menurut Jenning dan Dunne 1999 (dalam Rahmawati 2009 : 13) mengatakan bahwa, kebanyakan siswa mengalami kesulitan dalam mengaplikasikan matematika ke dalam situasi kehidupan real." Hal ini yang menyebabkan sulitnya matematika bagi siswa adalah karena dalam pembelajaran matematika kurang bermakna, dan guru dalam pembelajarannya di kelas tidak mengaitkan dengan skema yang telah dimiliki oleh siswa dan siswa kurang diberikan kesempatan untuk menemukan kembali ide-ide matematika. Mengaitkan pengalaman Jurnal Palapa | Volume 4. Nomor 1. (2016) Mei 135 
kehidupan nyata, anak dengan ide-ide dalam pembelajaran di kelas sangat penting dilakukan agar pembelajaran yang bermakna.

Menurut Suryanto dan Sugiman (2006: 2) keberhasilan siswa dalam menemukan ide dan konsep pembelajaran sangat ditentukan oleh guru. Nur dan Wikandari (2002: 2) mengatakan guru dapat membantu proses penemuan ide dan konsep tersebut dengan cara memberikan kesempatan kepada siswa untuk menemukan atau menerapkan ide-ide dengan strategi mereka sendiri sehingga informasi yang diperoleh siswa menjadi lebih bermakna dan relevan. Oleh karena itu, guru mempunyai tugas untuk menerapkan model yang tepat sesuai dengan materi yang disampaikan demi tercapainya tujuan kompetensi dasar siswa.

Berdasarkan pernyataan di atas, diperlukan usaha serius untuk memperbaiki kualitas pendidikan di tanah air. Salah satu usaha untuk memperbaiki/mereformasi adalah dengan mereduksi metode Tanjur dan melempar bola salju (T\&BS) yang merupakan inovasi dalam pembelajaran kelas khususnya untuk anak usia sekolah dasar yang memerlukan kolaborasi pembelajaran yang interaktif dan menyenangkan.

Sutarto Hadi (2006: 10) menyatakan bahwa masalah kontekstual dapat digali dari (1) situasi personal siswa, yaitu yang berkenaan dengan kehidupan sehari-hari siswa, (2) situasi sekolah/akademik, yaitu berkaitan dengan kehidupan akademik di sekolah dan kegiatan-kegiatan dalam proses pembelajaran siswa, (3) situasi masyarakat, yaitu yang berkaitan dengan kehidupan dan aktivitas masyarakat sekitar siswa tinggal, dan (4) situasi saintifik/matematik, yaitu yang berkenaan dengan sains atau matematika itu sendiri.

Metode T\&BS adalah penggabungan antara metode Tandur dan melempar "Bola Salju". yang merupakan bagian dari metode Quantum Teaching dan Snowball Throwing. Hal lain yang mendasari pentingnya 
penerapan metode pembelajaran T\&BS adalah paradigma pembelajaran efektif yang merupakan rekomendasi UNESCO, yakni : belajar mengetahui (Learning to know), belajar bekerja (Learning to do), belajar menjadi diri sendiri (Learning to be ). Trimo dan Rusantiningsih: 2008.

Penerapan metode pembelajaran T\&BS merupakan salah satu wujud aplikasi pembelajaran bermakna dalam mata pelajaran IPA. Melalui metode pembelajaran T\&BS, siswa dilibatkan secara holistik baik aspek fisik, emosional, dan intelektualnya.

Serangkaian kegiatan penerapan metode T\&BS merupakan refleksi dari sistem TANDUR, yakni : Tumbuhkan (memberikan appersepsi), Alami (memberikan tanggapan terhadap materi yang dipelajari), Namai ( memasangkan kartu kata sesuai gambar), Demonstrasikan ( melakukan Snowball Throwing ), Ulangi ( melakukan Tanya jawab secara acak), dan Rayakan (memberi reward).

Pembelajaran merupakan suatu proses interaksi antara guru dengan siswa. Metode pembelajaran yang diterapkan guru dikelas akan berpengaruh terhadap kemampuan siswa dalam menguasai materi pembelajaran yang diberikan. Dalam pembelajaran IPA guru masih menggunakan metode konvensional dan masih menggunakan cara mengajar yang monoton. Metode pembelajaran yang digunakan rata-rata masih menggunakan metode yang pendekatannya masih berpusat pada guru. Belum ada upaya dari guru untuk mengembangkan metode yang lebih kreatif untuk menarik minat belajar siswa, pembelajaran masih berpusat pada guru, padahal seharusnya siswa diajak untuk mengalami sendiri pembelajaran. Dan dengan pengubahan bermacam-macam interaksi yang ada didalam dan disekitar momen belajar. Guru juga harus mewujudkan suasana pembelajaran yang menyenangkan namun tetap 
dalam konteks belajar. Dengan demikian maka siswa akan mudah mengerti daripada hanya dengan teori saja.

Berpijak pada masalah yang ada diatas, maka salah satu metode pembelajaran yang tepat untuk meningkatkan hasil belajar siswa di SDN 1 Sesela yaitu dengan penerapan metode T\&BS. Karena T\&BS adalah suatu metode pembelajaran yang dirancang untuk memudahkan anak dalam belajar. T\&BS merupakan pembelajaran yang dirancang untuk membuat siswa senang, dari awal pelajaran sampai akhir pelajaran.

Keadaan yang menyenangkan itu diharapkan siswa tidak merasa terbebani dalam menerima pelajaran, karena dalam pembelajaran T\&BS dirancang sedemikian rupa sehingga siapapun yang mengikuti pelajaran akan merasa senang. Dengan situasi yang menggembirakan itu akan membuat semua materi yang diberikan oleh guru mudah diterima oleh siswa. Dengan penerapan metode T\&BS diharapkan dapat meningkatkan hasil belajar siswa.

Selain itu dalam pembelajaran T\&BS siswa mendapat perhatian apabila siswa dapat mengerjakan tugas dengan baik. Adanya penghargaan dari guru atau dari temannya tersebut siswa akan merasa termotivasi secara tidak langsung. Keadaan yang selalu menggembirakan itu siswa akan selalu berlomba-lomba untuk menyelesaikan tugas yang diberikan oleh guru, karena mereka tahu siapa yang dapat menyelesaikan tugas dengan baik akan selalu mendapat perhatian secara khusus.

Dalam pembelajaran T\&BS materi pembelajaran diberikan dengan berbagai cara misalnya dengan permainan dan lomba, sehingga seolaholah siswa tidak sedang belajar, padahal mereka belajar dengan penuh semangat. Guru dalam menyampaikan materi diikuti dengan humor, sehingga siswa tidak merasa takut, tidak merasa berat dalam menerima pelajaran. 


\section{METODE PENELITIAN}

Jenis penelitian ini adalah penelitian tindakan kelas. Penelitian tindakan kelas merupakan suatu pencermatan terhadap kegiatan belajar berupa sebuah tindakan, yang sengaja dimunculkan dan terjadi dalam sebuah kelas secara bersama. Tindakan tersebut diberikan oleh guru atau dengan arahan dari guru yang dilakukan oleh siswa (Arikunto, 2008:3). PTK dalam penelitian ini dilakukan oleh guru untuk memperbaiki kinerja sebagai guru, sehingga hasil belajar siswa menjadi meningkat.

Penelitian tindakan kelas ini dilaksanakan di kelas IV 2 SDN 8 Sesela Kecamatan Terara. Alasannya adalah bahwa selama ini dalam proses pembelajaran menunjukkan baik hasil maupun dalam diskusi kelompok belum maksimal, hal ini mengakibatkan hasil belajar siswa rendah. Diperkirakan juga karena belum maksimalnya proses pembelajaran, terutama penggunaan metode pembelajaran. Guru masih mengadopsi metode eksposisi sebagai satu-satunya metode.

Jumlah siswa 24 orang terdiri dari 12 laki-laki dan 12 perempuan, karakteristik siswa secara umum dikelas IV yaitu penurut dan senang bermain. Latar belakang keluarga siswa dari segi ekonomi yaitu menengah kebawah, kebanyakan siswa berasal dari lendang Belo dan Mujur. guru disekolah ini ada 4 orang pegawai negri dan 4 orang masih honor.

Pembelajaran dengan menggunakan metode T\&BS dinyatakan berhasil jika nilai minimal yang diperoleh siswa 70 dan ketuntasan belajar $80 \%$. Jika minimal 19 siswa $(80 \%)$ dari 24 siswa mendapat nilai minimal 
70 pada kegiatan pembelajaran dengan penggunaan metode T\&BS maka pembelajaran dinyatakan berhasil.

Instrument yang diperlukan dalam pengumpulan data PTK dapat dipahami dari dua sisi, yaitu sisi proses dan sisi hal yang diamati (Herawati Susilo, Husnul Chotimah dan Yuyun Dwitasari, 2008 : 67). Adapun didalam penelitian ini, peneliti mengambil data dengan menggunakan dua instumen penelitian yaitu lembar observasi kegiatan siswa dan guru serta hasil belajar siswa di uji dengan instrumen tes.

Data pengelolaan pembelajaran ini digunakan sebagai pedoman guru untuk memperbaiki pelaksanaan pembelajaran pada pertemuan berikutnya. Indikator tentang pengelolaan pembelajaran yang diamati adalah sebanyak 6 indikator, dimana setiap indikator terdiri dari 3 deskriptor. Skor aktivitas guru secara klasikal untuk masing-masing indikator yaitu:

Skor 3 diberikan jika semua (3) deskriptor tampak

Skor 2 diberikan jika (2) deskriptor tampak

Skor 1 diberikan jika (1) deskriptor tampak

Skor 0 diberikan jika tidak ada deskriptor yang tampak.

Hasil belajar sebagai data kuantitatif diperoleh dari hasil tes evaluasi secara individual untuk melihat peningkatan pemahaman siswa terhadap konsep materi gaya.

a. Menentukan kriteria hasil belajar siswa berpedoman pada rumus sebagai berikut :

Skor maksimal Ideal $: 100$

Skor minimal ideal $: 10$

b. Menentukan kriteria hasil belajar siswa digunakan skor standar yaitu : 


$$
\begin{aligned}
& \text { MI (Mean Ideal ) } \\
& \begin{aligned}
\text { minimal ) } & \frac{1}{2} \times(\text { skor maksimal }+ \text { skor } \\
& =\frac{1}{2} \times(100+10) \\
& =\frac{1}{2} \times(110) \\
& =55 \\
\text { SDI ( Standar Deviasi Ideal }) & =\frac{1}{6} \times(100-10) \\
& =\frac{1}{6} \times(90) \\
& =15
\end{aligned}
\end{aligned}
$$

Tabel 0.1. : Pedoman Kriteria Hasil Belajar Siswa

Konversi Nurkencana

\begin{tabular}{|c|c|l|}
\hline PEDOMAN KONVERSI & INTERVAL SKOR & KATEGORI \\
\hline MI + 2 SD s/d MI + 3SD & $86-100$ & Sangat berhasil \\
\hline MI + 1 SD s/d MI + 2 SD & $71-85$ & Berhasil \\
\hline MI \pm 1 SD & $40-70$ & Cukup berhasil \\
\hline MI - 2 SD s/d MI - 1 SD & $25-39$ & Kurang \\
berhasil
\end{tabular}

Data tentang hasil belajar siswa di analisis secara deskriptif yaitu dengan cara menghitung skor rata-rata kelas dengan rumus sebagai berikut : (Sudjana, 2011 : 109) 


$$
\bar{X}=\frac{\sum X}{N}
$$

Ket : $\quad X=$ Nilai rata-rata kelas (Mean)

$\sum \mathrm{X}=$ jumlah nilai siswa

$\mathrm{N}=$ banyak siswa

Nilai rata-rata kelas pada siklus I, dibandingkan dengan nilai rata-rata kelas pada siklus selanjutnya. Untuk mengetahui berhasil atau tidaknya siswa menguasai materi, maka data hasil belajar siswa yang diperoleh dianalisis terhadap ketuntasan belajar (KB) yang dihitung dengan menggunakan rumus sebagai berikut : (Zainal Aqib, dkk. 2009 : 205)

$$
\mathrm{KB}=\frac{\text { banyaknya siswa yang mendapat nilai } \geq 70}{\text { banyaknya siswa }} \times 100 \%
$$

\section{HASIL PENELITIAN DAN PEMBAHASAN}

Penelitian tindakan kelas ini dilaksanakan sebagai upaya untuk meningkatkan hasil belajar IPA siswa kelas IV SDN 8 Jenggik melalui penerapan metode T\&BS. Dari data hasil penlitian yang dilakukan selama dua siklus menunjukkan adanya pengaruh penerapan metode T\&BS terhadap peningkatan hasil belajar IPA siswa kelas IV SDN 8 Jenggik.

TANDUR adalah bagian dari Quantum teaching, yaitu Tumbuhkan ( guru menumbuhkan minat belajar atau pemberian motivasi), Alami ( siswa mengalami sendiri tentang hal-hal yang diajarkan), Namai ( siswa menamai gambar yang diberikan oleh guru), Demonstrasikan ( siswa melakukan kegiatan melempar "Bola Salju”), Ulangi (mengulang kembali kegiatan melempar "Bola Salju" untuk memperdalam pemahaman siswa), Rayakan (siswa merayakan kesuksesan dari pembelajaran). Sedangkan melempar "Bola Salju" yaitu meminta semua siswa menulis pertanyaan 
kemudian dikepal dan dilempar ke siswa yang lainnya. Jadi, metode T\&BS adalah penggabungan antara metode Tandur dan melempar "Bola Salju".

Penerapan pembelajaran metode T\&BS melalui beberapa tahap yaitu tahap perencanaan, pelaksanaan tindakan (yakni tahap awal, kegiatan inti, kegiatan akhir), observasi, dan refleksi. Pada siklus I, dan II semua kegiatan tersebut telah direncanakan dan terlaksana dengan baik.

Hasil penelitian pada siklus I (Tabel 4.4) sebagian siswa yang mencapai KKM dengan nilai rata-rata 73,63. Hal ini disebabkan karena siswa yang antusias menerima pelajaran dengan suasana yang baru, namun siswa juga belum terbiasa untuk maju kedepan kelas sehingga waktu disuruh maju siswa masih merasa malu, adapun beberapa siswa yang ribut dan tidak bisa terkontrol dengan maksimal oleh guru. Akan tetapi pada siklus berikutnya terjadi peningkatan pada hasil belajar siswa.

Ringkasan hasil yang diperoleh siswa pada tiap siklus bisa dilihat pada Tabel 0.2:

Tabel 0.2. Ringkasan Hasil Penelitian pada Tiap Siklus

\begin{tabular}{|c|c|c|c|c|c|c|}
\hline \multirow[b]{2}{*}{ Siklus } & \multirow{2}{*}{$\begin{array}{c}\text { Rata-Rata } \\
\text { Skor } \\
\text { Hasil } \\
\text { Belajar } \\
\text { Siswa }\end{array}$} & \multirow{2}{*}{$\begin{array}{l}\text { Persentase } \\
\text { Ketuntasan }\end{array}$} & \multicolumn{2}{|c|}{ Aktivitas Siswa } & \multicolumn{2}{|c|}{$\begin{array}{l}\text { Pengelolaan } \\
\text { Pembelajaran }\end{array}$} \\
\hline & & & $\begin{array}{l}\text { Rata- } \\
\text { rata } \\
\text { skor }\end{array}$ & Kriteria & Persentase & Kriteria \\
\hline I & 73,63 & $68,18 \%$ & 44 & aktif & 13 & Baik \\
\hline II & 77,09 & $82,60 \%$ & 48 & $\begin{array}{l}\text { Sangat } \\
\text { aktif }\end{array}$ & 17 & $\begin{array}{l}\text { Sangat } \\
\text { baik }\end{array}$ \\
\hline
\end{tabular}


Dari tabel 4.10 nampak bahwa pada siklus I persentase ketuntasan yang diperoleh siswa yaitu 68,18 \%, dengan persentase pengelolaan pembelajaran yang mencapai 13 sudah bagus dan masuk kriteria baik. Untuk hasil belajar ada 15 orang siswa tuntas yang nilainya mencapai standar kelulusan yaitu skor 70, dan belum mencapai target yang telah ditentukan. Hal ini disebabkan oleh : (1) siswa masih malu untuk bertanya langsung kepada guru; (2) masih ada siswa yang ribut saat kegiatan diskusi berlangsung; (3) guru belum memaksimalkan pengelolaan pembelajaran; (4) pembentukan kelompok yang tidak heterogen; (5) kegiatan melempar "Bola Salju" tidak maksimal dan tidak diadakan pengulangan.

Untuk mengatasi masalah yang terjadi pada siklus I maka akan dilakukan perbaikan pada siklus berikutnya, yakni siklus II.

Pada siklus II ini proses pembelajaran yang dilaksanakan hampir sama seperti proses pembelajaran yang dilakukan pada siklus I, namun ada penambahan media pembelajaran dan materi yang diajarkan. Pada siklus II dilakukan perbaikan berdasarkan kekurangan-kekurangan pada siklus I, adapun perbaikan yang dilakukan salah satunya yaitu : guru menekankan, mengarahkan, mengontrol pembelajaran, memotivasi siswa dan memaksimalkan penerapan metode pembelajaran T\&BS. Pada siklus II ini terjadi peningkatan nilai rata-rata bila dibandingkan dengan siklus I, yaitu dari 73, 63 menjadi 77,09. Aktivitas siswa juga mengalami peningkatan pada siklus II bila dibandingkan dengan siklus I yaitu 44 yang masuk dalam kategori aktif menjadi 48 yang masuk dalam kategori sangat aktif. Sedangkan untuk pengelolaan pembelajaran pada siklus II juga mengalami peningkatan yaitu 13 dengan kategori baik dan pada siklus II menjadi 17 dengan kategori sangat baik. 
Berdasarkan hasil penelitian yang telah dilakukan dapat dilihat bahwa terjadi peningkatan hasil belajar dari siklus I sampai siklus II, yaitu hasil dari preetest didapatkan 65\% siswa yang tuntas, sedangkan siklus I $68,18 \%$ dan siklus II $82,60 \%$ siswa yang tuntas. Dengan rincian kenaikan dari preetest ke siklus I sebesar 3 digit sedangkan dari siklus I ke siklus II mengalami kenaikan sebesar 14 digit. Ini tidak terlepas dari metode pembelajaran yang diterapkan. Peningkatan tiap siklus dikembangkan berdasarkan hasil refleksi pada akhir siklus, dan kegiatan pembelajaran yang dikembangkan selama proses pembelajaran. Jadi indikator ketercapaian tentang hasil belajar siswa telah mencapai target yaitu $80 \%$ ketuntasan belajar siswa dengan nilai $\geq 70$. Metode pembelajaran yang diterapkan adalah metode pembelajaran T\&BS yang menghendaki agar siswa mampu mengembangkan gagasan yang ada pada dirinya sehingga pembelajaran dirasakan bermakna dan membawa siswa pada pengalaman belajar yang mengesankan. Hal ini sejalan dengan pendapat yang dikemukakan oleh Ausubel (Ratna Wilis Dahar, 2009 : 94) yang mengemukakan bahwa "Belajar bermakna merupakan suatu proses dikaitkannya informasi baru pada konsep-konsep yang relevan yang terdapat dalam struktur kognitif seseorang".

Dengan demikian pelaksanaan pembelajaran dengan penerapan metode pembelajaran T\&BS dalam pembelajaran IPA mampu meningkatkan hasil belajar siswa kelas IV SDN 8 Jenggik. Hal tersebut disebabkan oleh penerapan metode T\&BS dalam PBM. Pelaksanaan pembelajaran dengan metode T\&BS yaitu guru harus berinteraksi membentuk hubungan baik dengan siswa; melibatkan siswa dalam berbagai kegiatan yang mengembangkan pemahaman dan kemampuan mereka dengan penekanan pada belajar yaitu siswa mengalami sendiri hal-hal yang diajarkan; mengatur kelas dengan cara menempelkan poster 
pada dinding kelas, mengatur tempat duduk dengan rapi untuk menciptakan suasana belajar yang nyaman, dan menyenangkan; mendorong siswa untuk mengungkapkan gagasannya, dan merayakan keberhasilan pembelajaran. Belajar adalah suatu aktivitas mental/psikis, yang berlangsung dalam interaksi aktif dengan lingkungannya, yang menghasilkan sejumlah perubahan dalam pengetahuan-pemahaman, keterampilan dan nilai-sikap. Perubahan itu bersifat secara relatif, konstan dan berbekas (Winkel, 2007:59).

Berdasarkan pembahasan tersebut maka penerapan metode T\&BS dalam pembelajaran IPA dapat meningkatakan hasil belajar siswa kelas IV di SDN 8 Jenggik.

Berdasarkan hasil analisis data dan hasil dari pembahasan penelitian dapat disimpulkan bahwa: Hasil belajar siswa pada Mata Pelajaran IPA Kelas IV SDN 1 Sesela semester II tahun ajaran 2011-2012 dapat meningkat dengan penerapan metode Tandur dan melempar "Bola Salju" (T\&BS). Proses pembelajaran yang dapat meningkatkan hasil belajar siswa yaitu guru menciptakan keadaan belajar yang nyaman melalui penataan ruang kelas, dan mewujudkan suasana pembelajaran yang menyenangkan namun tetap dalam konteks belajar melalui penerapan metode T\&BS yaitu menumbuhkan motivasi belajar siswa, mendatangkan pengalaman umum yang dapat dimengerti siswa, menyediakan gambar kemudian siswa menamai gambar tersebut, melakukan kegiatan melempar "Bola Salju", memberikan pengulangan kegiatan melempar "Bola Salju" untuk menunjukkan bahwa mereka tahu, dan merayakan keberhasilan dari pembelajaran. Akan tetapi dalam penerapan siklus I masih terdapat kekurangan namun telah di eliminir untuk penerapan siklus II sehingga dalam siklus II keunggulannya yang muncul. 
Peningkatan hasil belajar siswa dengan menggunakan metode T \& BS tingkat ketercapaian hasil belajar pada preetest $65 \%$ dan pada siklus I yaitu $68,18 \%$ menjadi $82,60 \%$ pada siklus II. Dengan rincian kenaikan dari preetest ke siklus I sebesar 3 digit, sedangkan dari siklus I ke siklus II mengalami kenaikan 14 digit.

\section{DAFTAR PUSTAKA}

Aqib Zainal,Siti J, Eko D,Khusnul K. 2009. Penelitian Tindakan Kelas. Bandung : CV.Yrama Widya.

Badan Standar Nasional Pendidikan. 2006. Panduan Penyusunan Kurikulum Tingkat Satuan Pendidikan Jenjang Pendidikan Dasar dan Menengah. Jakarta

Dahar, Ratna, Wilis, 2009. Teori-teori belajar dan pembelajaran. Jakarta : PT Erlangga

Deporter, Bobbi. 2010. Quantum Teaching (Mempraktikkan Quantum Learning di Ruang-ruang Kelas). Bandung : PT. Mizan Pustaka

Edihendri. 2009. Metodologi IPA SD. http:// pembelajaran IPA.co.id/url/hardy/fleer, diakses tanggal 16/03/2016.

Nurkencana, Wayan, 1983. Evaluasi Pendidikan. Surabaya :Usaha Nasional

Purwanto, 2011. Evaluasi Hasil Belajar. Yogyakarta : Pustaka Pelajar Sagala, Syaiful, 2011. Konsep Dan Makna Pembelajaran. Bandung : CV Alfabeta

Sudjana, Nana, 2011, penilaian hasil proses belajar mengajar. Bandung : PT Remaja Rosdakarya 
Suharsimi, Arikunto, Suhardjono dan Supardi, 2008. Penelitian Tindakan Kelas. Jakarta : Sinar Grafika

Sulistyorini, Sri, 2006. Pembelajaran IPA Sekolah Dasar. Semarang : Tiara Wacana

Sunartombs. 2009. Pengertian cooperative learning. http://sunartombs.wordpress.com/pengertian-cooperativelearning/,diakses tanggal 17/03/2016.

Suprijono, Agus. 2010. Cooperative Learning teori \& Aplikasi Paikem. Yogyakarta : Pustaka Pelajar

Susilo, Herawati, Husnul.C dan Yuyun.D, 2008. Penelitian Tindakan Kelas. Malang : IKAPI

Trimo dan Rusantiningsih. 2008. Meningkatkan hasil belajar IPS melalui kolaborasi metode Quantum teaching dan snawbal throwing, Hasil penelitian. http://re-searchengines.com/artikel/trimo.html), diakses tanggal 11/04/2016.

Winataputra, Udin S, 1992. Strategi Belajar Mengajar IPA. Jakarta : Depdikbud

Winkel, W. S. 2007. Psikologi Pengajaran. Yogyakarta : PT Media Abadi 